\title{
RESUltS OF STATISTIC RESEARCHES OF TPM APPLying STAgE Within THE ROMANIAN AUTOMOTIVE INDUSTRY
}

\author{
Popescu, R.; CAlefariu, G. \& TOMA, V.
}

Abstract: In this paper the researching results concerning the applying modalities of TPM within the companies of Romanian automotive industry. The total collectivity making object of the statistic sampling research consists in 106 companies, the sample set up by random methods including 31 companies.

Researches aimed aspects relied to the TPM concept, the advantages presented towards classical management methods. It also has been followed up identifying of adequate TPM model for the specific Romanian automotive industry and identifying its applying stages.

Key words: TPM, maintenance, management, automotive
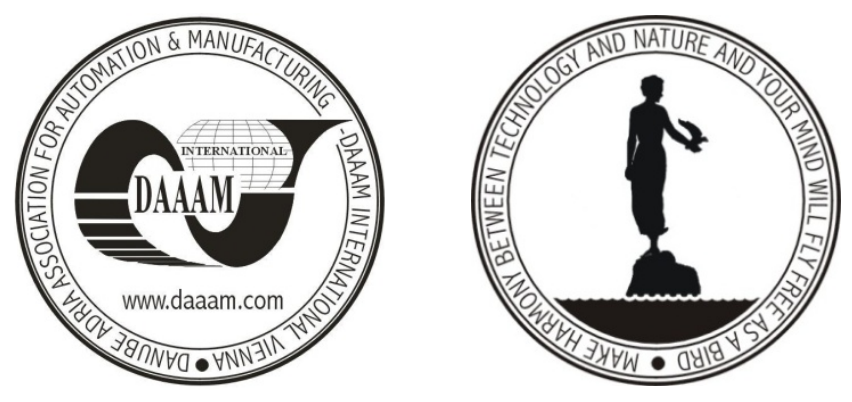

Authors' data: Popescu, R[adu $]^{*}$; Prof. Calefariu, G[avrila ${ }^{* *}$; Ph.D Toma, V[ictoria]***, *SC Stabilus SRL Romania, 130 Lunga St., 507055, Cristian, RO, **Transilvania University of Brasov, 8 Morii St., 507055, Cristian, RO, ***Transilvania University of Brasov, M. Viteazul, No. 5, 2200, Brasov, RO, popescu_crist@yahoo.com, gcalefariu@unitbv.ro, vtoma@unitbv.ro

This Publication has to be referred as: Popescu, R[adu]; Calefariu, G[avrila] \& Toma, V[ictoria] (2008). Results of Statistic Researches of TPM Applying Stage Within the Romanian Automotive Industry, Chapter 54 in DAAAM International Scientific Book 2008, pp. 629-640, B. Katalinic (Ed.), Published by DAAAM International, ISBN 978-3-901509-66-7, ISSN 1726-9687, Vienna, Austria DOI: $10.2507 /$ daaam.scibook.2008.54 